\title{
Franchising
}

\section{Personal liability for negligent misstatements}

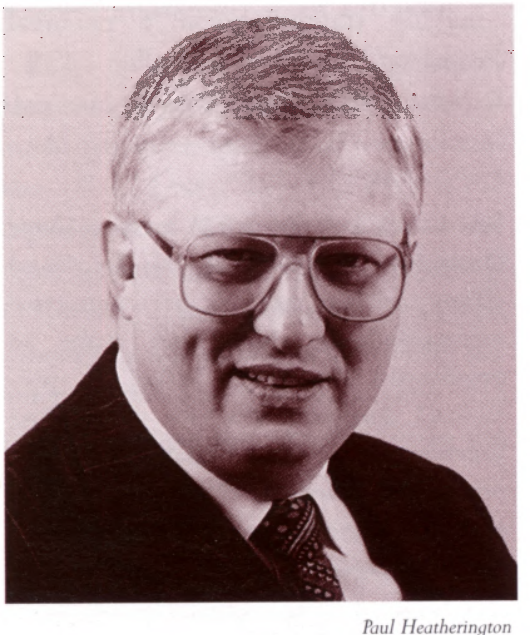

The managing director of a franchisor company incorporated with limited liability has been held personally liable for making negligent misstatements to a prospective franchisee in Williams $v$ Natural Life Health Foods Ltd [1997] BCC 605. In this note, I shall explain the facts of the case and summarise the law. I shall then analyse the implications of the decision to the franchise community.

\section{THE FACTS}

In October 1987, the plaintiffs, David Williams and Christine Reid, opened a health food shop in Rugby. They traded under franchise from Natural Life Health Foods Ltd (Natural Life). They had decided to go ahead because of a franchise brochure which gave details of Richard Mistlin's experience. Richard Mistlin was the founder of Natural Life. Apart from a nominal holding by Mrs Mistlin, the sole shareholder of Natural Life was Richard Mistlin. The negotiations for the sale of the franchise were mainly carried out by a nonshareholder director of Natural Life who was paid by commission. The financial projections which were prepared were substantially overstated. The forecast profit on expected sales for an 18-month period to April 1988 was projected at $£ 430,250$. The sales achieved were $£ 248,000$. The actual trading loss was $£ 38,000$.

The plaintiffs sued Natural Life for their losses of $£ 84,641$. When Natural Life, a limited liability company, was

\section{by Paul Heatherington}

dissolved, Richard Mistlin was joined in the action as a second defendant. The plaintiffs then went ahead with their action against Richard Mistlin alone.

Langley J delivered the judgment at first instance. At the trial Richard Mistlin did not give evidence. In the course of the trial there was no real explanation to justify the projected sales turnover figures. Richard Mistlin himself had run a health food business in Salisbury but this was his own shop and it did not belong to Natural Life. When the financial projections were given to the plaintiffs, Natural Life had no other franchisees with any relevant experience to provide a basis for the projections.

The total damages awarded to the plaintiffs were $£ 149,854.15$ which included interest of $£ 65,213.15$.

\section{THE APPEAL}

Natural Life had persuaded the plaintiffs to enter into, first, the franchise agreement with Natural Life and, secondly, a lease for a health food shop in Rugby relying on financial projections produced by Natural Life. The question for the Court of Appeal was whether Richard Mistlin was personally liable for those negligent misstatements.

The relevant law falls into two categories: negligent misstatements and the personal liability of a company director. There is little to say about the issue of negligent misstatements so far as the company is concerned. Natural Life was held to be in breach of its duty of care to the plaintiffs under the principles laid down in Hedley Byrne \& Co Ltd v Heller \& Partners Ltd [1964] AC 465 and Esso Petroleum Co Ltd v Mardon (1976) 1 QB 801. Hedley Byrne applies to negligent statements of facts. Esso Petroleum Co Ltd v Mardon further extends the doctrine to negligent forecasts.

On the issue of personal liability of directors, a number of authorities were considered. Giving the first of the three appeal judgments, Hirst LJ noted that a company director is not usually liable for negligent misstatements made by his company (Wah Tat Bank v Chan Cheng Kum
[1975] AC 507) and could only be fixed with personal liability if he assumed personal responsibility for negligent misstatements made on behalf of a company: Performing Rights' Society v Ciryl Theatrical Syndicate Ltd (1924) 1 KB 1. Hirst LJ emphasised that, particularly in the case of a one-man company, the court must take care to avoid nullifying the protection a company director would otherwise have resulting from the incorporation as a company Saloman v $A$ Saloman \& Co Ltd [1897] AC 22. But, it was held, if some special circumstances can be established, a plaintiff can, even in the case of a one-man company, pierce the veil of incorporation and establish personal liability on the part of a director: Fairline Shipping Corp v Adamson [1975] QB 180.

\section{SPECIAL CIRCUMSTANCES}

It is a question of fact and degree whether special circumstances for this purpose can be established in any case. In

\section{NOTE ON PILOT UNITS \\ Ethical franchising requires the franchisor to have successfully operated a business concept for a reasonable time in at least one pilot unit before it begins franchising. This means that a business concept should have been developed and shown to be successful so that profits earned are sufficient to provide a reasonable return on the franchisee's investment and to enable the franchisee to pay fees to the franchisor so that the franchisor earns sufficient to operate profitably.}

this case, the court decided that the sales projections were based on the personal abilities of Richard Mistlin and not on his experience as managing director of Natural Life, the franchisor company. In other words, Natural Life was selling the experience and expertise obtained by Richard Mistlin in his own Salisbury business. Giving the leading judgment, Hirst LJ stated:

'From what then was this knowledge and experience derived? Not, be it emphasised, from any company activity, since none of the other franchised shops had accumulated any experience, but rather from Mr Mistlin's personal experience in the Salisbury shop ('the 
pilot unit for the company's franchise network') which was owned and run by him personally and which had nothing whatsoever to do with his position as a director of the company. In other words the relevant knowledge and experience was entirely his qua Mr Mistlin, and not his qua director. Indeed I would go so far as to say that, in reality, $\mathrm{Mr}$ Mistlin held himself out as personally responsible for the only available figures to support the projections, as was indeed the fact.'

In concluding his judgment Hirst LJ expressed the view that there was no risk, on the particular facts of this case, of compromising the general concept of limited liability. Waite LJ agreed. A dissenting judgment was delivered by Sir Patrick Russell.

\section{LESSONS FOR THE FRANCHISE COMMUNITY}

Few franchisees who fail in business blame themselves. All franchisors run the risk of claims arising out of precontractual representations which they make to prospective franchisees either in pre-contract documentation such as franchise brochures, or in negotiations. Larger organisations may have difficulty controlling what may be said by a range of staff from the telephone receptionist to the franchise sales director. The Natural Life case points out that smaller franchisors have a higher exposure risk. This case does turn on its facts to some extent. The franchisor company was in its infancy. It had no real experience. The experience it offered to prospective franchisees was that of the single founding director. Its marketing literature claimed experience it did not have. When the financial projections were provided to the plaintiffs, the franchisor company had no other franchisees with any relevant experience to provide a basis for them.

For new businesses who want to franchise, this case sends these messages:

- learn about franchising before selling franchises;

- sell the franchises yourself. Do not use intermediaries;

- only claim that you have a proven system if you actually do have one;

- do not pluck sales figures out of the air and dress them up as profit forecasts. For a franchisee the most important factor when he buys will be working out realistic and supportable projections for sales, expenses and profits. No franchisee has the experience to do this. It is only a franchisor who is able to supply accurate information, with appropriate clarifications and disclaimers;

- officers of a company should avoid making statements in a personal capacity.

\section{FRANCHISORS' RISK}

Few franchisees who fail in business blame themselves. All franchisors run the risk of claims arising out of pre-contractual representations which they make to prospective franchisees either in precontract documentation such as franchise brochures, or in negotiations. Larger organisations may have difficulty controlling what may be said by a range of staff from the telephone receptionist to the franchise sales director.

Paul Heatherington

Eversheds (Newcastle upon Tyne)

\section{Trusts \& Equity}

\section{How dumb is the blind trust?}

\section{by Paul Matthews}

A common phenomenon in the modern offshore trust world is the socalled blind trust. Typically, a nominal trust fund - say $£ 10$ - is declared by a professional offshore trustee to be held on the terms of a lengthy and sophisticated trust deed. In substance, this amounts to discretionary trusts of income and capital, during the longest period allowed by the governing law, for the benefit of a defined class of objects. Again typically this class at the outset contains only one or two members. They will be charities of worldwide reputation, such as the International Red Cross.

The trust deed also confers power on the trustee to add further persons to the class. Some time after the original declaration of trust, the settlor decants substantial wealth into the hands of the trustee, on the same trusts. But, because the original deed is a unilateral declaration of trust by the trustee, the identity of this real settlor nowhere appears. Later still, the trustee - at the 'suggestion' of the settlor - appoints persons, who just happen to be his or her relatives or even himself or herself, into the class of objects, and then - surprise, surprise - the trustee appoints significant wealth out of the trust fund to them.

Such trusts have been known in the offshore world for years (see eg Re Gea Settlement, 17 March 1992, Royal Court of Jersey). Those who promote such trusts say they are cheap to set up, flexible, and may prevent intended beneficiaries having too many rights until appointed into the class (compare West $v$ Lazard Brothers \& Co (Jersey) Limited 1987-88 JLR N-22). All true. They are also a godsend to the shifty, the secretive and the downright fraudulent. And in any event the bit about charity is almost certainly a sham. In bad cases the whole thing will be.

\section{TRUST'S DISSERVICE}

But my purpose here is not to point out these obvious truths. It is to say that, even if the blind trust is utterly genuine, it may do a real disservice to those who create it. This is illustrated by a recent decision of the Isle of Man Court of Appeal (actually called the Staff of Government Division), Ahuja v Scheme Manager, Depositor's Compensation Scheme (8 April 1997, unreported).

Here a blind trust was set up in 1989 by eight persons, all related. Unusually, two of them appeared in the trust as settlors and trustees. But essentially it was a nominal sum held on discretionary trusts for a class which, at the date of setting up, contained only one object, namely the International Red Cross. This was also the beneficiary in default of appointment. One week after being created, two events occurred. First, the 